Jurnal Pemikiran Sosiologi Volume 6 No. 1, Januari 2019

\title{
Kemiskinan Perempuan Dayak Benawan di Kalimantan Barat sebagai Bentuk Kolonialisme Baru1
}

\author{
Nikodemus Niko²
}

\begin{abstract}
Abstraksi
Penelitian ini mendeskripsikan kondisi kemiskinan perempuan di komunitas adat Dayak Benawan Kalimantan Barat. Akses pengambilan keputusan yang terbatas bagi perempuan Dayak Benawa berimbas kepada adanya struktur pembagian kerja gender yang tidak adil. Tradisi adat yang tidak adil juga ikut menyebabkan kemiskinan. Studi ini menggunakan metode penelitian kualitatif deskriptif melalui observasi dan wawancara di lapangan dan data sekunder dari berbagai sumber pustaka seperti buku, dokumen dari kantor desa dan jurnal ilmiah.. Hasil penelitian menunjukkan bahwa kemiskinan yang dialami kaum perempuan Dayak Benawan tidak hanya bersifat kultural dan struktural saja, melainkan juga bersifat multidimensi. Diberlakukannya tradisi lokal justru menjadi alat pelemahan posisi perempuan secara politis di dalam komunitas. Hal semacam itu merupakan praktik yang melangengkan patriarki di dalam komunitas masyarakat Dayak Benawan. Narasi kolonialisme baru muncul dalam konteks dimana keterlibatan perempuan ditiadakan melalui tradisi adat sehingga memperparah kondisi kemiskinan khususnya bagi perempuan di dalam komunitas Dayak Benawan.
\end{abstract}

Kata kunci: kemiskinan, akses pengambilan keputusan perempuan, kolonialisme baru, adat tradisi, suku Dayak Benawan,

\begin{abstract}
This study describes the condition of women's poverty within ethnic community of Dayak Benawan in West Kalimantan. Access to decision-making is restricted for women of ethnic Benawa Dayak that has affected to unfair division of labor on gender base. Traditional custom also contributes to the deterioration of women poverty. This study employs qualitative method through observation and interviews combined with secondary data from various literature reference for example books, scientific journals and documents from village officials. The result of the study shows that poverty experienced by ethnic Benawan Dayak women is not only rooted in cultural and structural dimensions, but also multidimensional. The practice of traditional custom has become a tool to weaken women's political position within their community. Such practice is considered as perpetuating patriarchal structure within the Benawan Dayak community. The narrative of neocolonialism hence is emerged in the preservation of restricted involvement for decision making especially addressed to women through traditional custom among ethnic Dayak Benawan community members
\end{abstract}

Keywords: poverty, women access for decision making, traditional custom, neocolonialism, ethnic Benawan Dayak

\section{A. Latar Belakang}

Penelitian ini mendeskripsikan kemiskinan perempuan pada komunitas adat Dayak Benawan di wilayah pedesaan Kalimantan Barat. Kemiskinan perempuan meningkat tinggi selama zaman kolonial, artinya bahwa kemiskinan perempuan merupakan warisan kolonialisme (Luxemberg, 1951; Boserup, 1970). Kemiskinan perempuan merupakan satu diantara isu ketidakadilan gender. Pada masa kolonial, kaum perempuan digusur dari kegiatan produktif, dikarenakan oleh pembangunan yang merusak dan menghancurkan sumber daya

\footnotetext{
${ }^{1}$ Untuk kutipan atau sitasi artikel ini: Nikodemus Niko. 2019."Kemiskinan Perempuan Dayak Benawan di Kalimantan Barat sebagai Bentuk Kolonialisme Baru." Jurnal Pemikiran Sosiologi Vol 6 (1): 58-76.

2 Program Pascasarjana Sosiologi-Fisip, Universitas Padjajaran. Kontak penulis: nikodemusn@outlook.com
} 


\section{Jurnal Pemikiran Sosiologi Volume 6 No.1 2019 \\ Kemiskinan Perempuan Dayak Benawan di Kalimantan Barat sebagai Bentuk Kolonialisme Baru Nikodemus Niko}

yang menjadi landasan produksi pangan untuk kelangsungan hidup perempuan (Shiva, 1997). Hingga hari ini, kondisi kemiskinan warisan kolonial masih menjadi praktik yang berkepanjangan di wilayah pedesaan. Bagaimana dengan kasus praktik pada masyarakat adat Dayak Benawan di Kalimantan Barat?

Pada penelitian Wilson \& Aponte (1985) menyatakan bahwa kemiskinan di pedesaan Amerika sudah ditemukan sebelum abad ke-20, dimana pada saat itu pula terjadi social movement reform besar-besaran dalam merespon kemiskinan. Termasuk pula gerakan sosial perempuan di Amerika dalam merespon kemiskinan sudah terjadi secara besar-besaran (massive). Dalam konteks di Papua, Indonesia, kemiskinan lebih rentan menjadikan perempuan sebagai korban, baik dalam bentuk kekerasan fisik, psikologis maupun kesehatan (Subiyantoro, 2005).

Lai (2011) menyebutkan bahwa pada perempuan Orang Asli di Malaysia yang masih dalam kondisi miskin, mereka memanfaatkan hutan sebagai sumber mata pencaharian dan pendapatan. Secara teoritis, situasi ini disebut sebagai kemiskinan struktural yang artinya adalah suasana kemiskinan yang dialami oleh suatu masyarakat yang penyebab utamanya bersumber pada struktur yang memiskinkan, dan oleh karena itu dapat dicari pada struktur sosial yang berlaku sehingga mereka yang termasuk ke dalam golongan miskin tampak tidak berdaya mengubah nasibnya (Suyanto, 2001). Artinya bahwa Kondisi miskin ini bukan karena orang malas bekerja, melainkan karena ketidakberdayaan untuk menuju kehidupan yang lebih baik.
Keterbelakangan masyarakat pedalaman yang mendiami area pedesaan ini bukanlah hal baru, sudah banyak kajian yang mencoba mencari solusi untuk mengatasi permasalahan tersebut (lih. Diamond, 2012; Santoso, 2018), bahkan terjadi gerakan perlawanan masyarakat miskin dan tertindas (Crawshaw \& Jackson, 2015). Meskipun demikian keterbelakangan ini masih membelenggu masyarakat pedalaman yang seolah tidak ada jalan keluarnya. Kondisi keterpurukan masyarakat ini ditandai dengan masih tingginya angka kemiskinan, tingginya angka buta huruf serta kepasrahan pada nasib. Hal ini tidak saja dilihat sebagai kemiskinan struktural maupun kultural, melainkan kemiskinan yang multidimensi.

Kemiskinan multidimensi adalah kemiskinan yang berkait dengan berbagai dimensi antara lain dimensi sosial, budaya, sosial politik, lingkungan (alam dan geografis), kesehatan, dan budi pekerti (Suryawati, 2005). Pada realita kemiskinan masyarakat di desa pedalaman adalah terdapat banyak dimensi, termasuk struktur yang sengaja memiskinkan mereka, terlebih bagi perempuan yang tidak berdaya dan mengalami situasi miskin dua kali lipat dari laki-laki. Sebagai akibatnya, perempuan mengalami kemiskinan multidimesi. Perempuan dan anak-anak mengalami diskriminasi yang sistematik saat mengalami kemiskinan yang kronis (Cooper \& Bird, 2012).

Pada temuan penelitian Alkire \& Shen (2017) menyebutkan bahwa kemiskinan multidimensi di Cina selama kurun waktu 20102014 lebih banyak ditemukan pada rumah tangga di wilayah pedesaan. Sementara itu, bisnis pertanian yang banyak melibatkan perempuan di sepanjang 
Jurnal Pemikiran Sosiologi Volume 6 No.1 2019

Kemiskinan Perempuan Dayak Benawan di Kalimantan Barat sebagai Bentuk Kolonialisme Baru

Nikodemus Niko

pedesaan area sungai Mekong belum bisa menguraikan persoalan kemiskinan perempuan di Vietnam (Barry, 1996). Kedua penelitian ini (Alkire \& Shen 2017; Barry, 1996) sebatas melihat kemiskinan yang terjadi berdasarkan kebutuhan dasar dalam rumah tangga pada keluarga-keluarga petani di wilayah pedesaan.

Pada kasus di India, Khusro (1999) mengemukakan bahwa orang miskin secara absolut semakin waktu semakin bertambah secara massive, kemiskinan yang terjadi tidak hanya kondisional berdasarkan basic needs (kebutuhan dasar) saja melainkan sudah multidimensi. Privatisasi air menjadi salah satu indikator penyebab terjadinya kemiskinan pada kasus di Bangalore, hal tersebut berdampak negatif bagi perempuan dan anak-anak (Thara, 2017). Kajian penelitian Khusro (1999) dan Thara (2017) selain berfokus melihat pada kebutuhan dasar rumah tangga, juga melihat bahwa air sebagai sumber kehidupan di desa menjadi penting dalam menyebabkan kemiskinan karena adanya kepemilikan aset oleh pihak tertentu (privatisasi).

Menurut Delisle (2008) isu kemiskinan tidak bisa hanya dilihat satu arah saja, karena kemiskinan sangat kompleks dan multidimensi diantaranya indikator dalam melihat kemiskinan pada perempuan yaitu angka kematian ibu dan bayi, aksesibilitas dalam mendapatkan informasi kesehatan reproduksi dan tingkat keberdayaan perempuan. Lebih khusus, kajian Delisle (2008) menyoroti kemiskinan perempuan yang sifatnya multidimensi tidak hanya berbasis pada kebutuhan dasar dalam rumah tangga, tetapi lebih kepada akses-akses perempuan mendapatkan informasi, pendidikan serta pemberdayaan.

Pada penelitian ini, menemukan gap penelitian bahwa indikator multidimensi lain yang ingin peneliti lihat secara khusus adalah dimensi adat, akses kesehatan bagi perempuan, dan akses perempuan terhadap penguasaan lahan/tanah (ladang). Pada masyarakat adat Sasak, kemiskinan perempuan tidak hanya terjadi akibat struktur, melainkan lebih kepada rendahnya perlindungan komunitas atas kepemilikan dan pengelolaan aset oleh perempuan (Makinuddin, 2005).

Marjinalisasi perempuan tidak disebabkan oleh pemerintah saja, melainkan adanya jarak perempuan dengan otoritas pemerintah (aksesibilitas) (Tsing, 1998). Dalam melihat kemiskinan pada perempuan di komunitas adat Dayak Benawan, penulis sebisa mungkin menunjukkan perhatian pada formulasi gender; mendengarkan kedua belah pihak, laki-laki dan perempuan.

\section{B. Metode Penelitian dan Kerangka Teoritis}

Penelitian ini menggunakan jenis metode penelitian kualitatif deskriptif dengan eksplorasi data sekunder dan primer. Data primer dieksplorasi melalui pengamatan, wawancara dan interpretasi penulis pada penelitian lapangan di komunitas adat Dayak Benawan di Desa Cowet, Kecamatan Balai, Kabupaten Sanggau Kalimantan Barat. Analisis data lapangan dilakukan pada saat yang bersamaan dengan penulisan laporan penelitian ini, sehingga verifikasi data lapangan juga dilakukan pada saat yang bersamaan. 
Jurnal Pemikiran Sosiologi Volume 6 No.1 2019

Kemiskinan Perempuan Dayak Benawan di Kalimantan Barat sebagai Bentuk Kolonialisme Baru

Nikodemus Niko

Data sekunder dalam penelitian ini didapatkan melalui penelusuran tulisan-tulisan ilmiah seperti jurnal dan buku yang terkait dengan tema, serta melalui dokumen pemerintahan Desa Cowet.

\section{(1). Kerangka Teoritis Kemiskinan di Wilayah}

\section{Pedesaan}

Kemiskinan di wilayah pedesaan di Indonesia sudah menjadi isu yang berkepanjangan dimulai semenjak akhir masa orde baru tahun 1997, dimana kondisi ekonomi nasional memburuk (Suyanto, 2001). Kemiskinan di pedesaan berbeda dari kemiskinan di wilayah perkotaan, yang mana di perkotaan kemiskinan sebagai akibat dari rendahnya keterampilan (low-skilled), sedangkan kemiskinan di pedesaan dikarenakan rendahnya sumber daya serta kepemilikan tanah pada sektor pertanian yang tidak merata (Small \& Newman, 2001; Sender, 2002). Hal ini menurut Kumurur (2009) bahwa pengentasan dan pemerangan kemiskinan tidak cukup hanya melalui program anti-kemiskinan tanpa disertai dengan perubahan struktur ekonomi untuk memastikan aksesibilitas perempuan sumber-sumber daya.

Kemudian, kajian Kumar \& Prasad (2004) yang meneliti kemiskinan pada komunitas etnik Indo-Fijian di Fiji menyebutkan bahwa komunitas tersebut miskin sebagai akibat dari kondisi politik yang tidak berkeadilan terhadap etnik minoritas di negara tersebut. Disisi lain, Gradin (2015) juga menyebutkan bahwa faktor yang menyebabkan kemiskinan sangat tinggi pada kalangan etnik minoritas di China dikarenakan rendahnya kesempatan mengakses ekonomi, pendidikan yang rendah dan ketidakberdayaan dalam mengakses pasar. Niko (2016) menyebutkan pada komunitas Dayak Mali, kemiskinan perempuan berakibat pada kerentanan anak-anak perempuan untuk dinikahkan.

Penanganan yang serius oleh pemerintah belum banyak berdampak pada pengurangan jumlah masyarakat miskin, baik di tingkat nasional maupun tingkat lokal. Program-program yang berasal dari dana APBD menyasar tidak tepat sasaran, kemudian dana yang disediakan dalam rangka penanggulangan kemiskinan masih relatif kecil jika dibandingkan jumlah penduduk miskin (Kertati, 2013). Secara umum kemiskinan di Kalimantan Barat menurut data Badan Pusat Statistik (BPS) mencapai 756.810 orang yang hidup dibawah garis kemiskinan (Badan Pusat Statistik Kalimantan Barat, 2018), dimana jumlah orang miskin lebih banyak dijumpai di wilayah perkotaan yaitu sebanyak 387,080 orang dan jumlah orang miskin di wilayah pedesaan sebanyak 369.810 orang.

Artinya bahwa belum ada database BPS yang menyebutkan secara spesifik jumlah kemiskinan perempuan di Indonesia. Padahal perempuan dan anak-anak di wilayah pedesaan sangat rentan mengalami kemiskinan, seperti pada kondisi konflik di Cambodia yang mengakibatkan kerentanan kemiskinan pada perempuan (Ward \& Mouyly, 2013). Terlebih lagi, perempuan di wilayah pedesaan jauh dari akses perawatan kesehatan, berpenghasilan rendah, berpendidikan rendah, tidak adanya akses terhadap aset, dan gizi buruk (Balagopal, 2009).

Menurut Dao (2009) perempuan yang ada di negara-negara sedang berkembang (developing 
Jurnal Pemikiran Sosiologi Volume 6 No.1 2019

Kemiskinan Perempuan Dayak Benawan di Kalimantan Barat sebagai Bentuk Kolonialisme Baru

Nikodemus Niko

country) dan bekerja pada sektor pertanian, memiliki peran penting dalam pengurangan kemiskinan. Dalam agenda Sustainable Development Goals (SDGs) menargetkan tujuan pada kesetaraan gender dan pemberdayaan perempuan dan anak perempuan, yang mana hal ini sangat berkorelasi pada cita-cita untuk memberantas kemiskinan ekstrem (Bradwshaw, Chant, Linneker: 2017).

Pada kasus di Nigeria, Babatunde et al. (2012) menyebutkan bahwa sektor pertanian terutama ekspor produk pertanian sangat berperan penting dalam mengurangi kemiskinan dan ketidaksetaraan di Negeria. Berpijak pada pendapat Shiva (1997) lagi-lagi atas nama pembangunan yang merupakan perluasan ekonomi patriarki modern, yang mana pembangunan itu sendiri berartikan penghancuran perempuan, alam dan kebudayaan. Keterbatasan-keterbatasan tidak hanya melulu persoalan ekonomi semata, melainkan terdapat persoalan yang sudah multidimensional, dimana terdapat indikator-indikator seperti; dimensi sosial, pendidikan, kesehatan, kebijakan jaminan pemeliharaan kesehatan dan standar kualitas hidup (Suryawati, 2005; Budiantoro, Luhur \& Muto, 2015). Sementara itu, pada diskursus kemiskinan pedesaan di Indonesia, mereka akan menyembunyikan tubuh miskin tetangganya melalui diskursus berbagi kelebihan barang (Agusta, 2014).

Data kemiskinan multidimensional di Kalimantan Barat pada tahun 2014 menunjukkan bahwa sebanyak 2.060 .569 orang berada pada garis kemiskinan, dari jumlah keseluruhan penduduk sebanyak 4,40 juta orang. Hal ini berarti sebanyak 40,2\% penduduk di Kalimantan Barat masih hidup dibawah garis kemiskinan, dimana sebaran penduduk miskin paling banyak di wilayah pedesaan, yaitu sebanyak 1.726 .992 orang dan selebihnya berada di wilayah perkotaan (Budiantoro, Luhur \& Muto, 2015).

\section{(2). Perempuan dan Kemiskinan: Suatu Formulasi Pendekatan Gender}

Istilah gender berasal dari bahasa Latin; Genus-yang berarti jenis, macam, atau kelas (Davies, 2018). Lebih lanjut, Money (1955, dalam Davies, 2018) berargumen bahwa penggunaan istilah gender untuk menggambarkan makna menjadi seorang laki-laki atau perempuan terlepas dari perbedaan-perbedaan biologis. Kekeliruan dalam memahami dan mengintepretasikan gender pada suatu komunitas masyarakat, rentan menimbulkan ketidakadilan gender (gender inequalities) (Azwar, 2001).

Gender merupakan sebuah konstruksi sosial (social construction), yang kemudian berpengaruh pada performativitas (Fakih, 1996; Butler, 1990). Artinya bahwa gender yang muncul berdasarkan pemahaman tentang performances dan performativity yang kemudian merujuk pada proses pengulangan penampilan (enactment) atau performances yang menciptakan dan membentuk identitas (Austin, 1955 dalam Davies, 2018).

Pengentasan kemiskinan di wilayah pedesaan, bukan saja menjadi agenda pembangunan nasional, melainkan juga agenda pembangunan internasional yang sudah dirancang. Menurut Shiva (1997) agenda pembangunan yang dirancang elite nasional untuk mengeksploitasi dalam rangka kepentingan 
Jurnal Pemikiran Sosiologi Volume 6 No.1 2019

Kemiskinan Perempuan Dayak Benawan di Kalimantan Barat sebagai Bentuk Kolonialisme Baru

Nikodemus Niko

nasional, merupakan gaya penjajahan peninggalan kolonialisme. Dalam konsep kolonial, untuk menumbuhkan kapitalis harus memiliki tanah jajahan dengan demikian modal dapat dihimpun dengan mudah (Luxemberg, 1951).

Pada praktik dan diskursus kemiskinan ras dan etnis di pedesaan, bahkan menyembunyikan dan mengalihkan tubuh miskin dalam operasi prasangka-prasangka budaya (Agusta, 2014). Prasangka dan nilai ekonomi yang menetang alam, perempuan dan penduduk asli kemudian diasumsikan menjadi 'watak tidak produktif' (Foster, 1973). Oleh karena prasangka dan asumsi ini kemudian, penjualan lahan pada orang perorangan untuk mmengeruk produksi dan pendapatan berakibat tergusurnya kaum perempuan (Shiva, 1997).

Indraswari (2009) menyebutkan bahwa dalam wacana penghapusan kemiskinan tidak seharusnya mengabaikan persoalan perbedaan pengalaman laki-laki dan perempuan miskin dan perbedaan kapasitas laki-laki dan perempuan dalam melepaskan diri dari belenggu kemiskinan, karena perempuan pada umumnya (baik miskin dan tidak miskin) sejak awal berangkat dengan modal (pendidikan, akses ekonomi, dan lain-lain) yang berbeda dengan laki-laki. Menurut Adhi (2009) akar dari kemiskinan adalah persoalan pelayanan sanitasi yang buruk. Pada sisi lain, perempuan menjadi garda terdepan rumah tangga yang dituntut, termasuk mengatur sanitasi dan kesehatan dalam rumah tangga.

Kemiskinan pedesaan identik dengan aspekaspek agrikultur yang menjadi penopang kehidupan masyarakat desa. Dalam pengelolaan pertanian, gap gender sangat terlihat antara keparahan kemiskinan yang di alami laki-laki dan kemiskinan yang di alami perempuan pada negara-negara yang sedang berkembang (Dao, 2004). Artinya bahwa ketidakadilan gender merupakan akar persoalan atas kemiskinan perempuan. Fakih (1996) menguraikan ketidakadilan gender termanifestasikan dalam berbagai bentuk opresi ketidakadilan seperti; marginalisasi atau proses pemiskinan ekonomi, subordinasi atau anggapan tidak penting dalam keputusan politik, pembentukan stereotipe atau melalui pelabelan negatif, kekerasan (violence), beban kerja lebih panjang dan lebih banyak (burden), serta sosialisasi ideologi nilai peran gender.

\section{(3). Kemiskinan Bebasis Struktur Pada Masyarakat Adat: Pendekatan Karl Marx}

Masyarakat bukan suatu wadah, melainkan aksi, yaitu aksi sosial (social action) (Veeger, 1985). Lebih lanjut lagi, Veeger (1985) menyebutkan bahwa masyarakat sebagai proses sosial dipandang dari dua segi dalam kenyataan; pertama, masyarakat dapat ditinjau dari segi anggotanya yang membentuk, mendukung, mununjang, dan meneruskan suatu pola kehidupan bersama tertentu yang disebut masyarakat atau yang berusaha untuk mengubahnya. Kedua, masyarakat dapat ditinjau dari segi pengaruh strukturnya atas anggotanya, tanpa kepemimpinan, tanpa bahasa, tanpa hukum, tanpa keluarga, tanpa ekonomi, tanpa pertahanan, tanpa moralitas, agama dan lain-lain, maka individu akan jatuh ke dalam suatu keadaan. 
Jurnal Pemikiran Sosiologi Volume 6 No.1 2019

Kemiskinan Perempuan Dayak Benawan di Kalimantan Barat sebagai Bentuk Kolonialisme Baru

Nikodemus Niko

Masyarakat adat merupakan sekelompok masyarakat yang mendiami wilayah-wilayah pedalaman di Kalimantan, masih bertani subsisten. Penekanan identitas pada orang Dayak bahkan masih dianggap sebagai masyarakat primitif, yang masih berburu kepala, pengelompokan sosial di rumah panjang, memburu dan mengumpulkan, serta adanya ritual-ritual kematian (Maunati, 2012; King, 2013). Sehingga hal ini masih rentan menimbulkan marjinalisasi. Marjinalisasi yang terjadi, yaitu: dari sudut pandang elit, "masyarakat primitif", berbeda dari komunis, tidak dianggap serius berbahaya melainkan liar tidak terbinamereka agak mirip dengan petani desa biasa, tetapi dengan beberapa ciri khas (Tsing, 1998).

Kemiskinan tidak lagi dipahami hanya sebatas ketidakmampuan ekonomi, tetapi juga kegagalan memenuhi hak-hak dasar dan perbedaan perlakuan bagi seseorang atau sekelompok orang dalam menjalani kehidupan secara bermartabat. Hak-hak dasar yang diakui secara umum meliputi terpenuhinya kebutuhan pangan, kesehatan, pendidikan, pekerjaan, perumahan, air bersih, pertanahan, sumberdaya-alam, dan lingkungan hidup, rasa aman dari perlakukan atau ancaman tindak kekerasan dan hak untuk berpartisipasi dalam kehidupan sosial-politik, baik bagi perempuan maupun laki-laki. Perampasan hak-hak tersebutlah yang disebut sebagai proses pemiskinan.

Sosiolog sering mendiskusikan transisi dari sistem dunia tradisional menuju sistem moderen dengan konsep "diferensiasi" atau "spesialisasi fungsional." Pergeseran dari sistem skala kecil menuju peradaban agraris dan kemudian kepada masyarakat moderen, bisa dilihat sebagai suatu proses diversifikasi dari dalam yang bersifat progresif (Giddens, 2005). Arus globalisasi membawa sistem yang tadinya bersifat tradisional menjadi serba instan. Perusahaan bisnis, khususnya korporasi transnasional, dapat mencengkeram kekuatan ekonomi, dan memiliki kapasitas untuk mempengaruhi kebijakan politik. Oleh karenanya, kemiskinan serta kesenjangan berlaku semakin tajam antara kaum marjinal terhadap kaum berada.

Globalisasi telah menciptakan ruang dimana negara tidak lagi menjadi satu-satunya aktor dalam ekonomi politik global. Itu merupakan fakta yang sepertinya harus diakui kebenarannya. Ada banyak aktor yang kini merepresentasikan diri sebagai "penguasa" yang melampaui kemampuan negara bangsa dan masyarakat dunia. Aktor yang dimaksud adalah perusahaan-perusahaan multinasional (MNCs) dan lembaga-lembaga multilateral (IMF, World Bank, WTO). Gerakan sipil lintas batas negara bangsa (misalnya, Green Peace) juga menjadi aktor penting lainnya, tetapi tidak sekuat kedua aktor yang disebutkan sebelumnya. Keberadaan aktoraktor ini telah membuat otonomi negara semakin berkurang (Winarno, 2004).

Dalam pandangan Marx (1984) terdapat dua kelas yang selalu bertentangan dimana terdapat kelas borjuis atau pemilik modal dan kelas pekerja (proletar). Dalam hal ini adalah terdapatnya struktur kelas yang menggambarkan si "miskin" dan si "kaya". Menurut Marx (1984) pengejaran keuntungan merupakan hal yang hakiki dalam kapitalisme. Dengan modal sekecil-kecilnya untuk mendapatkan untung yang sebesar-besarnya. Untuk mengejar nilai surplus yang dapat meningkatkan 
Jurnal Pemikiran Sosiologi Volume 6 No.1 2019

Kemiskinan Perempuan Dayak Benawan di Kalimantan Barat sebagai Bentuk Kolonialisme Baru

Nikodemus Niko

modal, perpanjangan hari kerja dan eksploitasi buruh merupakan salah satu cara yang digunakan kapitalis. Untuk menekan biaya produksi, penurunan upah sampai dibawah nilainya pun dipaksakan oleh pengusaha.

Kondisi di atas disebut oleh Marx sebagai 'pemfakiran' (pauperisation) atau 'pemelaratan' (emiseration). Disparitas relatif yang terus membesar antara kelas pekerja dan kelas kapitalis ketika kelas kapitalis terus menimbun kekayaan, upah kaum buruh tidak pernah dapat naik untuk mencukupi kebutuhan hidupnya, dan dipaksa untuk hidup dalam kemiskinan, sehingga keberadaan mereka akan menjadi penduduk surplus relatif bagi kapitalis. Kemiskinan kelas pekerja/proletar diartikan sebagai kondisi kemiskinan yang bukan kemiskinan alamiah yang diakibatkan oleh kekurangan sumber daya, akan tetapi merupakan hasil buatan organisasi kontemporer dari produksi industri. Dalam artian bahwa kemiskinan yang terjadi secara struktural.

\section{(4). Pendekatan Teori Feminisme Liberal tentang Perempuan dan Kemiskinan}

Feminisme liberal sudah muncul pada awal abad-20, kemudian pada tahun 60-an menjadi gerakan yang massive dan mendominasi pemikiran tentang perempuan di seluruh dunia, khususnya Dunia Ketiga atau negara-negara berkembang (Fakih, 1996). Termasuk di Indonesia, perkembangan gerakan feminisme bertahap mengalami kemajuan dari waktu ke waktu. Artinya bahwa waktu yang dilihat sebagai dimensi fenomena sosial sekaligus sebagai aspek perubahan sosial (Sztompka, 2007).
Pada dasarnya gerakan feminisme ini merupakan salah satu bagian dari peristiwa perkembangan sosiologi, dimana sosiologi berkaitan dengan kejadian sehari-hari, peristiwa biasa, serta peristiwa sosial yang berulang-ulang pada masyarakat (Bachtiar, 2006). Gerakan feminisme berkembang di negara-negara barat pada tahun 1960-an atas gerakan pembebasan perempuan (Friedman, Metelerkamp, \& Posel, 2011). Termasuk didalamnya gerakan feminisme liberal, yang terekspresi dalam program global yang banyak dikenal sebagai program Women in Development (perempuan dalam pembangunan) (Fakih, 1996).

Pandangan dasar feminisme liberal adalah bahwa tiap laki-laki atau perempuan mempunyai hak dalam mengembangkan kemampuan dan rasionalitasnya secara optimal (Saptari \& Holzner, 2016). Feminisme liberal percaya bahwa keterbelakangan kaum perempuan, selain akibat dari sikap irrasional yang sumbernya karena berpegang teguh pada nilai-nilai tradisional, juga karena perempuan tidak di beri akses partisipasi dalam pembangunan (Fakih, 1996).

Pada dasarnya kerangka kerja feminisme liberal lebih kepada memperjuangkan persoalan masyarakat yang tertuju pada 'kesempatan yang sama dan hak yang sama' bagi setiap individu, termasuk didalamnya kesempatan dan hak yang sama antara kesempatan dan hak kaum perempuan (Fakih, 1996).

Ekspresi utama dari teori ketimpangan gender adalah feminisme liberal, yang berargumen bahwa perempuan bisa mengklaim kesamaan dengan laki-laki atas dasar kapasitas esensial 
Jurnal Pemikiran Sosiologi Volume 6 No.1 2019

Kemiskinan Perempuan Dayak Benawan di Kalimantan Barat sebagai Bentuk Kolonialisme Baru

Nikodemus Niko

manusia sebagai agen moral yang bernalar, bahwa ketimpangan gender adalah akibat dari pola seksis dan patriarkis dari divisi kerja, dan bahwa kesetaraan gender dapat dicapai dengan mengubah divisi kerja melalui pemolaan ulang institusiinstitusi kunci-hukum, pekerjaan, keluarga, pendidikan dan media (Bem, 1993; Ritzer \& Goodman, 2004).

Elemen utama argumen feminis liberal adalah klaim kesetaraan gender. Dokumen kunci untuk memahami basis klaim ini adalah Declaration of Sentiments yang dikeluarkan oleh konvensi hakhak perempuan pertama di Seneca Fallsm New York, pada 1848. Oleh karena itu feminis liberal berdasarkan pada keyakinan bahwa: (1) semua manusia mempunyai ciri esensial tertentukapasitas sebagai agen moral dan nalar dan aktualisasi diri; (2) pelaksanaan kapasitas ini dapat dijamin melalui pengakuan legal atas hak-hak universal; (3) ketimpangan antara lelaki dan perempuan adalah diciptakan secara sosial (socially constructed), dan tidak ada dasarnya dalam "alam"; (4) perubahan sosial untuk kesetaraan dapat dicapai dengan mengajak publik yang rasional dan dengan menggunakan negara (Ritzer \& Goodman, 2004).

Diskursus feminis kontemporer ini telah mengembangkan argumen-argumen dengan memperkenalkan konsep gender sebagai cara untuk memahami semua ciri socially constructed dari ideide identitas kelamin dan dipakai untuk menghasilkan ketimpangan antara orang yang dianggap lelaki dan orang yang dianggap perempuan. Penjelasan feminis liberal kontemporer tentang ketimpangan gender kemudian beralih ke keterkaitan dari empat faktor-konstruksi sosial dari gender, divisi tenaga kerja gender, doktrin dan praktik ruang publik dan privat, serta ideologi patriarkis.

Keterkaitan antara permasalahan dalam makalah ini dengan teori yang digunakan yaitu perempuan Dayak Benawan tidak menemukan pengalaman mereka dalam dunia publik seperti pendidikan, kerja sektor formal, politik karena masih dibatasi oleh diskriminasi, marjinalisasi dan pelecehan. Dalam hal ini adalah masih terjadi ketimpangan terhadap pemenuhan hak dan perlindungan perempuan miskin di pedesaan. Kemampuan perempuan untuk bersaing dalam karir dan profesi dirintangi oleh tuntutan dari ruang privat (Wadfogel, 1997; Ritzer \& Goodman, 2004).

\section{Temuan: Kemiskinan Multidimensi Perempuan Dayak Benawan}

Secara administratif terdapat desa yang termasuk ke dalam wilayah adat Dayak Benawan di Kecamatan Balai Kabupaten Sanggau. Tiga desa tersebut yaitu Desa Cowet, Desa Bulu Bala dan Desa Melugai. Wilayah desa yang termasuk ke dalam klasifikasi desa pedalaman dan desa tertinggal yaitu Desa Cowet. Penduduk di Desa Cowet masih tergolong kelas menengah ke bawah (miskin). Niko (2018) menyebutkan bahwa perempuanperempuan Dayak Benawan di Desa Cowet masih mengalami double burden karena kondisi miskin yang dialami.

Dayak Benawan merupakan salah satu subsuku Dayak yang bermukim di Desa Cowet, Kabupaten Sanggau, Kalimantan Barat, bersama dengan suku Melayu dan Dayak Mali. Dari sejumlah 
Jurnal Pemikiran Sosiologi Volume 6 No.1 2019

Kemiskinan Perempuan Dayak Benawan di Kalimantan Barat sebagai Bentuk Kolonialisme Baru

Nikodemus Niko

1.538 orang penduduk yang bermukim di Desa Cowet, Dayak Benawan merupakan suku dengan jumlah terbanyak.

Suku Dayak Benawan menyebut diri mereka sebagai 'orang Benawan', yang artinya adalah 'kami bersuku Dayak Benawan' (Niko, 2018). Orang Benawan hidup berkelompok di perkampungan. Di Desa Cowet, orang Dayak Benawan tersebar di beberapa kampung, di antaranya kampung Pejalu, Bangang, Munguk Tawak, Cowet, Dusun, Munguk Mayang, dan Tanjung.

Kedudukan perempuan Dayak Benawan dapat dilihat dalam struktur sosial melalui konstruksi peran dan status di dalam rumah tangga, struktur kemasyarakatan maupun struktur adat (Niko, 2018). Ketika membicarakan perempuan di dalam struktur, akan berkaitan langsung dengan aktivitas keseharian mereka. Hal ini terkait dengan situasi ekonomi perempuan yang dengan sengaja dilemahkan oleh struktur dan kultur. Kemudian pada nilai politik, adat dijadikan sebagai alat dalam penguasaan perempuan.

Pada kehidupan rumah tangga masyarakat Dayak Benawan sangat bergantung pada alam. Kebutuhan pangan keluarga mereka di dapat dari hasil alam seperti sayur-sayuran, lauk-pauk, dan beras/nasi. Sayur-sayuran didapatkan dari hutan, kebun karet dan pekarangan ladang. Sementara lauk-pauk didapatkan dari mencari ikan di sungai dan berburu tupai dan tikus di hutan. Sedangkan beras/nasi didapatkan dari berladang yang masih subsisten.

Chandraningrum (2016) menyebutkan bahwa kelompok orang yang paling miskin di dunia adalah mereka yang memiliki karakteristik: 1) mereka tinggal di perdesaan; 2) bertahan pada sektor buruh agrikultur untuk dapat bertahan hidup; dan 3) tidak memiliki tanah yang bisa digarap (petani tanpa tanah). Berdasarkan karakteristik tersebut, komunitas perempuan Dayak Benawan yang merupakan petani subsisten dan tinggal di perdesaan merupakan kelompok yang rentan mengalami kemiskinan.

Masyarakat Dayak Benawan di Desa Cowet lebih banyak yang bekerja sebagai masyarakat peladang dengan intensitas berladang sebanyak dua kali dalam setahun. Dalam pekerjaan ini perempuan merupakan aktor utama melakukan aktivitas di ladang. Pada pekerjaan pertanian ini laki-laki/suami adalah penentu dalam keputusan membuka lahan ladang awal. Sedangkan perempuan sebagai pendamping. Namun, setelah lahan dibuka, perempuan lah yang akan intens bekerja di ladang. Mulai dari ikut menebang pohon kemudian membakarnya, hingga menuai ani-ani padi.

$$
\text { Jenis pekerjaan di ladang dilakukan }
$$
bersama, baik perempuan maupun laki-laki. Lakilaki menebang pohon-pohon yang besar, mengangkut ranting kayu yang sisa-sisa saat dibakar, dan membuat dio umek (gubug tani) di tengah ladang. Sedangkan perempuan bekerja menebang pohon yang ukuran kecil, menebas rumput, menanam padi, menunggu padi saat sudah menguning, dan menuai ani-ani. Dalam hal ini jenis kelamin laki-laki atau perempuan akan menentukan mereka akan mengerjakan apa di ladang.

Seperti wilayah Kalimantan lainnya, terdapat dua musim di Kampung Pejalu; musim hujan dan kemarau. Musim hujan akan 


\section{Jurnal Pemikiran Sosiologi Volume 6 No.1 2019 \\ Kemiskinan Perempuan Dayak Benawan di Kalimantan Barat sebagai Bentuk Kolonialisme Baru \\ Nikodemus Niko}

mempengaruhi pekerjaan laki-laki yang beraktivitas di luar rumah, seperti menyadap karet dan pekerjaan di ladang, sehingga laki-laki tidak ada pekerjaan dan hanya di rumah saja. Sementara perempuan selain tidak dapat menyadap karet dan bekerja di ladang, perempuan tetap mengerjakan pekerjaan di rumah.

Musim kemarau tiba keluarga Dayak Benawan dapat survive untuk melangsungkan kehidupan. Ketika musim kemarau air karet akan menyusut dan kian mengering, airnya tidak deras lagi karena setiap hari di sadap. Pendapatan mereka akan berkurang saat musim kemarau. Oleh karena itu untuk menopang kebutuhan keluarga maka perempuan melakukan aktivitas nyikep untuk mendapatkan lauk-pauk dan mereka memetik daun karet yang masih muda untuk sayur.

Adat dan tradisi merupakan aturan tertinggi yang dipatuhi dan dipercaya masyarakat suku ini, dimana tidak ada satupun dari anggota masyarakat yang dapat melawan adat dan mengubah tradisi. Praktik adat dan kepercayaan terhadap tradisi sangat kuat pada masyarakat Dayak Benawan, termasuk didalamnya praktik pembagian kerja berdasarkan jenis kelamin. Jenis kelamin perempuan dan laki-laki akan memposisikan mereka akan mengerjakan apa.

Pada adat-adat tertentu, perempuan merupakan pihak yang tidak berdaya dalam status perkawinan. Setelah melangsungkan pernikahan adat, istri tidak boleh membantah apa kata suami atau istri tidak bisa menentang pendapat atau keputusan suami sebagai kepala rumah tangga, mereka sebut pamalik. Kondisi ini menunjukkan bahwa adat Dayak Benawan masih kental dengan sistem patriarki, dimana otoritas kuat ada pada lakilaki. Artinya adalah kemiskinan yang terjadi pada perempuan Dayak Benawan merupakan warisan kultur yang sudah mendarah daging bersama kehidupan masyarakat. Dalam suatu wilayah tertentu, perbedaan budaya dapat menjadi perangkap suatu komunitas dalam keadaan miskin, yang artinya bahwa perbedaan budaya antarwilayah semestinya menjadi aspek dalam melihat kemiskinan (Ningaye, 2011).

Kemiskinan multidimensi meneropong kemiskinan tidak hanya dari aspek ekonomi delam melihat kemiskinan, tetapi berbagai aspek lain yang merupakan penyebab orang miskin. Aspek dalam rumah tangga yang seringkali terjadi adalah kemiskinan bahan bakar, pendapatan rumah tangga, kondisi pemukiman (lingkungan rumah) (Todd \& Steele, 2006). Pada kasus perempuan Dayak Benawan menunjukkan bahwa pekerjaan-pekerjaan ganda yang dikerjakan oleh perempuan tidak dianggap sebagai penindasan dan eksploitasi. Mereka menganggap bahwa dengan melakukan pekerjaan yang berat, bukan merupakan beban ganda, melainkan kewajiban perempuan di dalam rumah tangga.

Pembagian kerja tradisional dalam keluarga petani biasanya dianggap "alami”, dalam pengertian jelas sejak semula ditimbulkan oleh perbedaan jenis kelamin itu sendiri (Boserup, 1984). Peran gender yang terjadi pada masyarakat Dayak Benawan tidak terlepas dari tradisi masyarakat setempat, dalam hal ini lokalitas berpengaruh dalam pembentukan pembagian kerja antar gender. Pembagian kerja 


\section{Jurnal Pemikiran Sosiologi Volume 6 No.1 2019 \\ Kemiskinan Perempuan Dayak Benawan di Kalimantan Barat sebagai Bentuk Kolonialisme Baru Nikodemus Niko}

gender inilah yang kemudian ikut berkonstribusi dalam pemiskinan perempuan secara struktur.

Kemiskinan pedesaan identik dengan aspekaspek agrikultur yang menjadi penopang kehidupan masyarakat desa. Dalam pengelolaan pertanian, gap gender sangat terlihat antara keparahan kemiskinan yang di alami laki-laki dan kemiskinan yang di alami perempuan pada negara-negara yang sedang berkembang (Dao, 2004). Dalam hal ini, perempuan yang mengalami miskin akan lebih parah dibandingkan dengan laki-laki yang mengalami miskin.

Proposisi pertama bahwa pendidikan merupakan faktor utama perempuan Dayak Benawan tidak dilibatkan dalam kebijakan sektor publik dan domestik, namun ternyata tradisi juga berpengaruh besar dalam menentukan 'perempuan seharusnya mengerjakan apa'. Hingga hari ini tradisi Dayak Benawan belum berubah, dan memposisikan perempuan pada sektor domestik, sedangkan sektor publik dikuasai oleh laki-laki. Artinya adalah sistem adat yang menempatkan perempuan sebagai 'yang lain' dalam masyarakat, menyebabkan perempuan secara kultur dimiskinkan.

\section{Keterbatasan tingkat pendidikan} perempuan memang menjadi salah satu faktor ketidakadilan gender yang terjadi pada masyarakat Dayak Benawan. Keterbelakangan dari pendidikan formal ini juga berimbas pada kemiskinan perempuan Dayak Benawan. Pada kasus ini terdapat pula perempuan Dayak Benawan yang berpendidikan tinggi (paling tinggi tamat SMA) namun masih dibatasi akses bagi perempuan di ruang publik.
Ketidakadilan terhadap perempuan pada tradisi Dayak Benawan ini pada dasarnya di klaim tidak ada oleh pengurus adat dan pejabat desa, bahkan perempuan Dayak Benawan sendiri tidak menganggap hal tersebut sebagai ketidakadilan. Namun, narasi ketidakadilan tersebut terdeskripsi pada saat ketika wawancara dengan pihak perempuan. Manifestasi ketidakadilan gender dilihat dari pembagian kerja di sektor domestik (rumah tangga/keluarga), akses pendidikan dan kesempatan memasuki ruang publik (lembaga adat, pegawai desa, dan kelompok tani), yang mana perempuan belum dianggap setara dengan laki-laki.

Timbulnya kepercayaan yang kuat masyarakat Dayak Benawan pada tradisi, sama halnya dengan kepercayaan mereka kepada adat dan agama yang mereka anut. Penguasaan laki-laki terhadap ruang publik dan ruang domestik adalah dianggap sebagai tradisi yang dipercayai masyarakat setempat. Oleh sebab itu perempuan tidak mendapatkan tempat/posisi tertentu pada pengambilan kebijakan di ruang publik bahkan pada ruang domestik.

Pendidikan saja tidak dapat menjadi jaminan (guarantee) bagi perempuan dapat akses bekerja di sektor publik formal seperti lembaga adat dan pegawai desa. Akibatnya, pada sektor publik non-formalpun perempuan belum banyak dilibatkan, seperti kelompok tani yang ada di kampung mereka. Bukan hanya itu saja, bahkan tingkat pendidikan tidak berpengaruh terhadap sistem tradisi pada setiap keluarga (sektor domestik), perempuan masih 'mengekor' pada lakilaki dalam hal kebijakan dalam rumah tangga. Oleh karena itu, kemiskinan yang terjadi pada 
Jurnal Pemikiran Sosiologi Volume 6 No.1 2019

Kemiskinan Perempuan Dayak Benawan di Kalimantan Barat sebagai Bentuk Kolonialisme Baru

Nikodemus Niko

perempuan Dayak Benawan secara merata dan terjadi pada tiap tingkat umur dan tingkat pendidikan.

\section{Analisis Kritis: Kemiskinan Perempuan Dayak Benawan Sebagai Bentuk Kolonialisme Baru}

Masyarakat di Desa Cowet masih tersubordinasi dalam akses pelayanan publik; belum memiliki akses listrik negara, jauh dari pusat layanan kesehatan, dan keterbatasan akses air bersih. Keterbatasan infrastruktur jalan juga mengakibatkan akses menuju ibukota kecamatan sulit untuk di jangkau. Menurut peneliti hal ini menjadi penghambat bagi perempuan Dayak Mali di Desa Cowet untuk mengakses pelayanan publik, seperti; pendidikan, pelayanan sosial dan pelayanan kesehatan.

Demikian pula dengan akses ekonomi, perempuan Dayak Mali hanya mengandalkan alam sebagai penopang ekonomi keluarga. Sebagai sumber kehidupan, alam dihormati sebagai sesuatu yang sakral dan evolusi manusia diukur menurut kemampuan manusia menyatu dengan irama-irama dan pola-pola alam secara intelektual, emosional dan spiritual (Shiva, 1997). Peneliti menemukan bahwa perempuan Dayak Benawan di Desa Cowet bermata pencaharian utama dengan menyadap pohon karet (motong'k) dan berladang (kume'k) sebagai mata pencaharian utama.

Mulyanto, dkk. (2009) menegaskan bahwa keikutsertaan perempuan dalam kerja-kerja pertanian lebih dilatari kelas sosial rumah tangganya dalam pemilikan lahan, bagi perempuan dari rumah tangga buruh tani, kerja-kerja pertanian merupakan tulang punggung perolehan uang tunai dan gabah untuk kebutuhan rumah tangganya. Menurut Indraswari (2009) ketimpangan gender memperparah kemiskinan perempuan dan sebaliknya kemiskinan itu sendiri berkontribusi terhadap semakin tajamnya ketimpangan gender.

Kemiskinan merupakan situasi masalah kompleks yang dipengaruhi oleh berbagai faktor, antara lain; pendapatan, pendidikan, lokasi, gender, dan kondisi lingkungan, kemiskinan di Indonesia dicirikan oleh banyaknya rumah tangga yang berada di sekitar garis kemiskinan, sebagai akibat, meski tidak tergolong miskin mereka rentan terhadap kemiskinan (Khomsan, dkk., 2015). Subjek yang miskin tidak hanya menubuh pada individu, melainkan meluas dalam keluarga, kelompok, etnis bahkan kewilayahan (Agusta, 2014).

Kemiskinan disebabkan oleh beberapa faktor yang saling terkait satu sama lain, seperti mengalami kecacatan, memiliki pendidikan rendah, tidak memiliki modal atau keterampilan untuk berusaha, tidak tersedianya kesempatan kerja, terkena pemutusan hubungan kerja (PHK), tidak adanya jaminan sosial (pensiun, kesehatan, kematian), atau hidup di lokasi terpencil dengan sumber daya alam dan infrastruktur yang terbatas (Suharto, 2009).

Kaum sosialis memandang bahwa sistem kapitalisme sebagai sistem yang tidak adil dan irasional, yang memang sudah seharusnya dihapuskan. Banyak akibat yang ditimbulkan, termasuk wabah kemiskinan yang kian melanda negara-negara berkembang. Standarisasi kemiskinan menurut Wright (1996) adanya gap 


\section{Jurnal Pemikiran Sosiologi Volume 6 No.1 2019 \\ Kemiskinan Perempuan Dayak Benawan di Kalimantan Barat sebagai Bentuk Kolonialisme Baru \\ Nikodemus Niko}

ekonomi antara pendapatan dan pengeluaran di dalam rumah tangga (household), yang mana setiap rumah tangga harus membayar asuransi, pajak dan pengeluaran untuk kebutuhan rumah tangga, jika tidak maka disebut miskin (poor). Padahal kenyataan kemiskinan tidak hanya berakar pada ekonomi semata. Seperti pada masyarakat Marori dan Kanum di Papua, kemiskinan terjadi ditandai dengan hilangnya ruang-ruang hidup masyarakat, seperti pemusnahan sagu yang merupakan sumber kehidupan bagi masyarakat (Suryawan, 2018).

Dan hingga saat ini pun, fenomena kemiskinan masih tersebar luas di negara berkembang seperti di Indonesia. Seperti kemiskinan di Flores yang menurut Tolo (2016) dewasa ini disebabkan oleh akumulasi melalui perampasan, yakni sejarah penjajahan yang panjang, ketimpangan struktur agraria, dan depolitisasi massa rakyat. Namun Marx tidak sepakat, dan ia mengkritik kaum sosialis awal karena mereka tidak memandang kapitalisme dalam konteks historis. Menurut Marx, kapitalisme telah mengakhiri ketidakadilan dan irasionalitas feodal, namun kapitalisme telah menggantikannya dengan ketidakadilan dan irasionalitasnya sendiri (Fink, 2010).

Perempuan Dayak Benawan mengalami kemiskinan (pemiskinan) oleh kultur dan struktur yang kemudian menambat mereka tidak dapat berkutik di dalam kubang kemiskinan. Kemiskinan pada dasarnya tidak hanya berkenaan dengan rendahnya tingkat konsumsi dan pendapatan masyarakat, melainkan juga rendahnya tingkat pendidikan dan kesehatan, ketidakberdayaan untuk berpartisipasi dalam proses pengambilan keputusan publik, ketidakmampuan menyampaikan aspirasi, dan rendahnya mutu hidup manusia (Handayani, 2009). Artinya bahwa kemiskinan pada perempuan Dayak Benawan juga bersifat multidimensi.

Marx menyebutkan bahwa masyarakat sipil akan terancam krisis jika dibiarkan berjalan sendiri. Pernyataan ini memang mengandung multi-tafsir, dapat diterjemahkan bahwa masyarakat sipil (yang miskin) apabila terjadi pembiaran oleh negara maka akan terjadi suatu krisis. Krisis yang dimaksud dapat berupa krisis kemanusiaan seperti kelaparan, wabah penyakit, peperangan, dan berbagai masalah sosial lainnya.

Memang sudah sangat banyak program pembangunan yang bebasis dan berupaya untuk mensejahterakan masyarakat dalam rangka pengentasan kemiskinan. Pada masyarakat Dayak Benawan sudah ada program seperti Bantuan Langsung Tunai (BLT), Program Keluagra Harapan (PKH), dan berbagai program lainnya. Namun, kebijakan pembangunan dan berbagai program penanggulangan kemiskinan yang dikembangkan seringkali tidak kurang memperhatikan karakteristik dan konteks lokal masyarakat miskin, sehingga banyak paket kebijakan yang kemudian menjadi lahan 'proyek' bagi segelintir oknum para elit.

Beragam kebijakan yang tidak tepat sasaran dan menjadi proyek untuk memperkaya segelintir oknum inilah merupakan gaya kolonial yang diterapkan pada masyarakat kontemporer hari ini. Dari sinilah menurut Marx; negara adalah alat dari kelas yang berkuasa, kendati negara terkesan 
Jurnal Pemikiran Sosiologi Volume 6 No.1 2019

Kemiskinan Perempuan Dayak Benawan di Kalimantan Barat sebagai Bentuk Kolonialisme Baru

Nikodemus Niko

sebagai semacam penengah yang netral di antara berbagai kepentingan yang saling bersaing.

Pendekatan Marx mengandaikan bahwa sangatlah penting untuk mengkaji kekuatankekuatan yang beroperasi dalam masyarakat kontemporer. Hal ini berarti Marx sangat mendukung bahwa harus adanya kajian pendahulu untuk dapat memahami masyarakat dalam konteks lokal. Sangat ironis apabila negara mengucurkan sejumlah dana dan program kepada masyarakat miskin tanpa terlebih dahulu mempertimbangkan struktur sosial di masyarakat lokal yang notabenenya terpola dan terstratifikasi atas berbagai dimensi.

Kemiskinan yang dialami oleh kaum proletariat telah menyadarkan mereka akan ketidakberuntungan mereka dari sistem kapitalis. Melihat kondisi kaum buruh pada sistem kapitalisme, Marx menginginkan sistem baru dalam sistem masyarakat, yaitu sosialisme, dimana tidak ada kepemilikan pribadi (private property) dari kaum borjuis, yang ada adalah kepemilikan bersama atau komunal. Kondisi demikian terjadi pada masyarakat Dayak Benawan sekitar sepuluh tahun silam dalam status kepemilikan tanah/lahan. Namun semakin derasnya arus modernisasi hari ini, perlahan mengikis konsep lokalitas akan kepemilikan komunal menjadi kepemilikan pribadi.

Dalam sosialisme, sistem ekonomi yang digunakan bersifat subsisten, yaitu produksi hanya untuk memenuhi kebutuhan hidup anggota masyarakat saja dan tidak untuk ditumpuk sebagai modal seperti pada sistem kapitalis. Untuk mewujudkan ini, menurut Marx kelas pekerja harus bersatu dan melakukan revolusi, seperti halnya kaum borjuis/kapitalis melakukan revolusi terhadap kaum feodal.

Sosialisme yang ditandai oleh revolusi kaum buruh akan penghapusan hak milik pribadi atas sarana-sarana produksi, sehingga tidak ada lagi penghisapan oleh satu kelas terhadap kelas lainnya, dalam hal ini penghisapan kaum kapitalis terhadap kaum proletariat. Si "miskin" kemudian diberi kesempatan untuk merubah nasib menjadi lebih baik, meskipun berjalan sangat lamban dan butuh waktu yang sangat lama. Artinya bahwa jika sosialisme bangkit kembali pada komunitas adat, maka eksistensi kolonialisme yang berbaju kapitalisme akan tergusur dan dihancurkan.

\section{E. Kesimpulan}

Ketimpangan gender dalam meneropong kemiskinan perempuan Dayak Benawan adalah lakilaki yang menjadi tonggak kebijakan di sektor publik maupun domestik ini tidak dilihat berdasarkan pendidikan, jabatan, dan kelas sosial, namun berdasarkan tradisi masa lalu yang sudah menempatkan bahwa laki-laki lah yang menjadi pemimpin-dalam segala hal-bagi perempuan. Kondisi ini kemudian melemahkan kedudukan perempuan dalam lembaga adat, struktural pemerintahan desa, dan keluarga. Ketidaksetaraan laki-laki dan perempuan dalam akses ini memperparah kemiskinan yang terjadi terhadap perempuan Dayak Benawan.

Kemiskinan perempuan yang terjadi di wilayah pedesaan adat Dayak Benawan dan secara terstruktur ini, tidak dapat berdiri sendiri, sehingga dalam penanganan masalahnya pun menuntut 
Jurnal Pemikiran Sosiologi Volume 6 No.1 2019

Kemiskinan Perempuan Dayak Benawan di Kalimantan Barat sebagai Bentuk Kolonialisme Baru

Nikodemus Niko

pemahaman dan kecermatan. Tidak dapat dinampikkan pulab bahwa arus globalisasi dan modernisasi yang semakin pesat berkembang di tengah-tengah masyarakat hari ini, menjadi penyumbang paling besar terhadap kemiskinan dan kesenjangan dalam komunitas adat Dayak Benawan. Usulan Marx bahwa sistem kapitalisme harus ditiadakan, kemudian diganti oleh sistem sosialisme yang diharapkan mampu membawa kaum miskin dan marjinal berproses menuju kehidupan lebih baik.

Senada dengan pemikiran Marx, feminisme liberal mengamini kesetaraan akses baik laki-laki dan perempuan dalam berproses keluar dari zona perangkap kemiskinan. Sistem adat Dayak Benawan yang sarat dengan nilai patriarki merupakan eksistensi kolonialisme hari ini. Praktik kemiskinan (pemiskinan) perempuan di pedesaan harus dihapuskan melalui perjuangan kesetaraan gender dan pemberdayaan perempuan. Hal ini bukan hanya bersinggungan dengan isu Hak Asasi Manusia, melainkan juga prasyarat pembangunan yang inklusif, adil dan berkelanjutan. Sebagaimana yang telah kita ketahui bahwa Indonesia melalui UU No. 7 Tahun 1984 telah meratifikasi konvensi internasional tentang penghapusan segala bentuk perlakuan diskriminatif terhadap perempuan, yang kemudian dikenal dengan sebutan CEDAW (The Convention on the Elimination of All Forms of Discrimination Against Women).

\section{Daftar Pustaka}

Adhi, E. T. 2009. "Pelayanan Sanitasi Buruk: Akar dari Kemiskinan." Jurnal Analisis Sosial Vol 14 (2): 76-87.

Agusta, I. 2014. Diskursus, Kekuasaan, dan Praktik Kemiskinan di Pedesaan. Jakarta: Yayasan Obor Indonesia.

Alkire, S., \& Shen, Y. 2017. "Exploring Multidimensional Poverty in China: 2010 to 2014." Research on Economic Inequality Vol 25 (1): 161-228.

Azwar, W. 2001. Matrilokal dan Status Perempuan dalam Tradisi Bajapuik: Studi Kasus Tentang perempuan dalam Tradisi Bajapuik. Yogyakarta: Galang Press.

Babatunde, M. A., et al. 2012. "Exports Trade, Employment and Poverty Reduction in Nigeria." International Journal of Social Economics Vol 39 (11): 875-899.

Bachtiar, W. (2006). Sosiologi Klasik: dari Comte hingga Parsons. Bandung: Remaja Rosdakarya.

Badan Pusat Statistik Kalimantan Barat. (2018). Profil Kemiskinan Provinsi Kalimantan Barat September 2018. Pontianak: Badan Pusat Statistik Kalimantan Barat.

Balagopal, G. (2009). "Access to Health Care among Poor Elderly Women in India: How far the Policies Respond to Women's Realities." Gender and Development Vol 17 (3): 481491.

Barry, K., (Ed.). 1996. Vietnam's Women in Transition. Great Britain: MacMillan Press, Ltd.

Bem, S. 1993. The Lenses of Gender: Transforming the Debate on Sexual Inequality. Yale: Yale University Press.

Boserup, E. 1970. Women's Role in Economic Development. London: Allen and Unwin. 
Jurnal Pemikiran Sosiologi Volume 6 No.1 2019

Kemiskinan Perempuan Dayak Benawan di Kalimantan Barat sebagai Bentuk Kolonialisme Baru

Nikodemus Niko

Boserup, E. 1984. Peranan Wanita dalam Perkembangan Ekonomi. Jakarta: Yayasan Obor Indonesia.

Bradwshaw, S., Chant, S., \& Linneker, B. 2017. "Gender and Poverty: What we know, don't know, and need to know for Agenda 2030." Gender, Place \& Culture Vol 24 (12): 16671688.

Budiantoro, S., Luhur, F. M., \& Muto, S. 2015. Penghitungan Indeks Kemiskinan Multidimensi di Indonesia 2012-2014. Jakarta: Prakarsa.

Butler, J. 1990.. Gender Trouble: Feminism and the Subversion of Identity. New York: Routledge.

Chandraningrum, D. 2016. "Perempuan Surokonto Wetan: Tumbal Tanah Kendeng, Ketahanan Pangan, dan MST (Movimento Sem Terra)", dalam Candraningrum (ed) Ekofeminisme IV. Salatiga: Parahita Press.

Cooper, E., \& Bird, K. 2012. “Inheritance: A Gendered and Intergenerational Dimension of Poverty." Development Policy Review Vol 30 (5): 527-541.

Crawshaw, S., \& Jackson, J. 2015. Tindakan-tindakan Kecil Perlawanan: Bagaimana Keberanian, Ketegaran, dan Kecerdikan dapat Mengubah Dunia. Yogyakarta: Insist Press.

Dao, M. Q. 2004. "Rural Poverty in Developing Countries: An Empirical Analisys." Journal of Economic Studies Vol 31(6): 500-508.

Dao, M., Q. 2009. "Poverty, Income Distribution and Agriculture in Developing Country." Journal of Economic Studies Vol 36 (2): 168-183.

Davies, S. G. 2018. Keberagaman Gender di Indonesia. Jakarta: Yayasan Obor Indonesia.

Delisle, H. F. 2008. "Poverty: the Double Burden of Malnutrition on Mothers and the Integrational Impact." Annual New York Academy of Sciences Vol 11 (36): 172-284.
Diamond, J. 2012. The World Until Yesterday: Apa yang Dapat Kita Pelajari dari Masyarakat Tradisional? Jakarta: Gramedia.

Fakih, M. 1996. Analisis Gender dan Transformasi Sosial. Yogyakarta: Pustaka Pelajar.

Fink, H. 2010. Filsafat Sosial: Dari Feodal hingga Pasar Bebas. Yogyakarta: Pustaka Pelajar.

Foster, M. G. 1973. Traditional Societies and Technological Change. Delhi: Allied Publishers.

Friedman, M., Metelerkamp, J., \& Posel, R. 1987. "What is Feminism?". Agenda: Empowering. Women for Gender Equity Vol 1(1): 3-24.

Giddens, A. 2005. Konsekuensi-Konsekuensi Modernitas. Yogyakarta: Kreasi Wacana.

Gradin, C. 2015. "Rural Poverty and Ethnicity in China: Measurement of Poverty, Deprivation, and Economic Mobility." Research on Economic Inequality No 23: 221247.

Handayani, N. 2009. "Menyimak Kehidupan Keluarga "Miskin"." Jurnal Analisis Sosial Vol 14 (2): 1-12.

Hefner, R. W. 1999. Geger Tengger: Perubahan Sosial dan Perkelahian Politik. Yogyakarta: LkiS.

Indraswari. 2009. "Perempuan dan Kemiskinan." Jurnal Analisis Sosial Vol 14 (2): 40-52.

Kertati, I. 2013. "Analisis Kemiskinan Kota Semarang berdasarkan Data Pendataan Program Perlindungan Sosial (PPLS)." Jurnal Riptek Vol 7(1): 27-38.

Khomsan, dkk. 2015. Indikator Kemiskinan dan Misklasifikasi Orang Miskin. Jakarta: Yayasan Obor Indonesia.

Khusro, A. M. 1999. The Poverty of Nation. Great Britain: MacMillan Press, Ltd.

King, V. T. 2013. Kalimantan Tempo Doloe. Depok: Komunitas Bambu. 
Jurnal Pemikiran Sosiologi Volume 6 No.1 2019

Kemiskinan Perempuan Dayak Benawan di Kalimantan Barat sebagai Bentuk Kolonialisme Baru

Nikodemus Niko

Kumar, S., \& Prasad, B. 2004. "Politics of Race and Poverty in Fiji: A case of Indo-Fijian Community." International Journal of Social Economics Vol 31 (5/6): 469-486.

Kumurur, V. A. 2009. "Pembangunan dan Kemiskinan Perempuan Kota." Jurnal EKOTON Vol 9 (1): 73-86.

Lai, W. T. 2011. "Gender and Livelihood: A Case Study of the Mah Meri and the Oil Palm Plantations of Carey Island." Asian Journal of Women's Studies Vol 17(2): 7-36.

Luxemberg, R. 1951. The Accumulation of Capital. London: Routledge and Kegan Paul.

Makinuddin. 2005. "Kemiskinan dan 'Janji Surga' Bagi Perempuan Sasak.” Jurnal Perempuan. Vol 1 (42): 61-72.

Marx, K. 1847. Kemiskinan Filsafat (Terj. Tahun 2007). Bogor: Hasta Mitra.

Maunati, Y. 2004. Identitas Dayak: Komodifikasi dan Politik Kebudayaan. Yogyakarta: LkiS.

Mulyanto, D., Dkk. 2009. Kapitalisasi Dalam Penghidupan Perdesaan. Bandung: Yayasan AKATIGA.

Niko, N. 2016. "Anak Perempuan Miskin Rentan Dinikahkan: Studi Kasus Hukum Adat Dayak Mali Kalimantan Barat." Jurnal Perempuan, Vol 21 (1): 83-95.

Niko, N. 2018. Perempuan Dayak Benawan: Kedudukan pada Struktur Domestik dan Publik. Yogyakarta: Deepublish.

Ningaye, P. 2011. "Ethno-Cultural Diversity and Multidimensional Poverty Differential in Cameroon." International Journal of Dovelopment Issues Vol 10(2): 123-140.

Ritzer, G., \& Goodman, D. J. 2004. Teori Sosiologi Modern. Jakarta: Kencana.

Santoso, D. 2018. Penduduk Miskin Transient: Masalah Kemiskinan yang Terabaikan. Jakarta: Yayasan Obor Indonesia.
Saptari, R., \& Holzner, B. 2016. Perempuan Kerja dan Perubahan Sosial: Sebuah Pengantar Studi Perempuan. Jakarta: Kalyanamitra.

Sender, J. 2002. “Women's Struggle to Escape Rural Poverty in South Africa." Journal of Agrarian Change Vol 2 (1): 1-49.

Shiva, V. 1997. Bebas dari Pembangunan: Perempuan, Ekologi dan Perjuangan Hidup di India. Jakarta: Yayasan Obor Indonesia.

Small, M. L., \& Newman, K. 2001. "Urban Poverty after the Trully Disadvantaged: The Rediscovery of the Family, the Neighborhood, and Culture." Annual Reviews Sociology Vol 27 (1): 23-45.

Subiyantoro, E. B. 2005. "Perempuan Miskin di Ujung Negeri." Jurnal Perempuan Vol 1 (42): 33-44.

Suharto, E. 2009. Kemiskinan dan Perlindungan Sosial di Indonesia. Bandung: ALFABETA.

Suryawan, I. N. 2018. Ruang Hidup yang Redup: Gegar Ekologi Orang Marori dan Kanum di Merauke Papua. Yogyakarta: Penerbit Basa Basi.

Suryawati, C. 2005. "Memahami Kemiskinan Secara Multidimensional." The Journal of Public Financial Management Vol 8 (3): 121-129.

Suyanto, B. 2001. "Kemiskinan dan Pemberdayaan Masyarakat Miskin." Jurnal Masyarakat, Kebudayaan dan Politik Vol 1 (4): 25-42.

Sztompka, P. 2004. Sosiologi Perubahan Sosial (Edisi Pertama). Jakarta: Prenada.

Thara, K. 2017. "In Troubled Waters: Water Commodification, Law, Gender, and Poverty in Bangalore." Gender and Development Vol 25 (2): 253-268.

Todd, S., \& Steele, A. 2006. "Modelling a Culturally Sensitive Approach to Fuel Poverty." Structural Survey Vol 24(4): 300-310. 
Jurnal Pemikiran Sosiologi Volume 6 No.1 2019

Kemiskinan Perempuan Dayak Benawan di Kalimantan Barat sebagai Bentuk Kolonialisme Baru

Nikodemus Niko

Tolo, E. Y. S. 2016. "Akumulasi Melalui Perampasan dan Kemiskinan di Flores." MASYARAKAT: Jurnal Sosiologi Vol 21 (2): 173-204.

Tsing, A. L. 1998. Di Bawah Bayang-bayang Ratu Intan: Proses Marjinalisasi pada Masyarakat Terasing. Jakarta: Yayasan Obor Indonesia.

Veeger, K. J. 1985. Realitas Sosial: Refleksi Filsafat Sosial atas Hubungan Individu-Masyarakat dalam Cakrawala Sejarah Sosiologi. Jakarta: Gramedia.

Waldfogel, J. 1997. "The Effect of Children on Women;s Wages." American Sociological Review Vol 62 (2): 209-217.

Ward, K., \& Mouyly, V. 2013. "The Importance of Being Connected: Urban Poor Women's Experience of Self-help Discourse in Cambodia." Gender \& Development Vol 21 (2): 313-326.

Wilson, W. J., \& Aponte, R. 1985. "Urban Poverty." Annual Reviews Sociology Vol 11 (2): 231258.

Winarno, B. 2014. Dinamika Isu-Isu Global Kontemporer. Yogyakarta: CAPS.

Wright, R. E. 1996. "Standardized Poverty Measurement." Journal of Economic Studies Vol 23 (4): 3-17. 